$\begin{array}{rr}\text { Moleküler Biyoloji ve Genetik / Moleculer Biology and Genetic } & \text { DOI: 10.21597/jist.1028843 } \\ \text { Geliş tarihi / Received: } 26.11 .2021 & \text { Araştırma Makalesi / Research Article }\end{array}$

Atıf İçin: Uygur Göçer E, 2021. Bazı Nigella sativa L. Genotiplerinde RAPD Markırları Kullanılarak DNA Sitozin Metilasyon Polimorfizminin Belirlenmesi. Iğdır Üniversitesi Fen Bilimleri Enstitüsü Dergisi, 11(Özel Sayı): 3488-3495.

To Cite: Uygur Göçer E, 2021. Determination of DNA Cytosine Methylation Polymorphism Using RAPD Markers in Some Nigella sativa L. Genotypes. Journal of the Institute of Science and Technology, 11(Special Issue): 3488-3495.

\title{
Bazı Nigella sativa L. Genotiplerinde RAPD Markırları Kullanılarak DNA Sitozin Metilasyon Polimorfizminin Belirlenmesi
}

\author{
Emine UYGUR GÖÇER ${ }^{1}$
}

ÖZET: Epigenetik, DNA baz değişimi olmaksızın gen ifadesi ve fonksiyonundaki kalıtsal değişimler olarak tanımlanmaktadır. DNA'da metilasyon ve histon proteinlerindeki kimyasal modifikasyonlar bitkilerde en çok çalışılan iki epigenetik mekanizmadır. Epigenetik araştırmalarda düşük işlem hacimli ve yüksek işlem hacimli DNA metilasyon saptama teknikleri vardır. Düşük işlem hacimli tekniklerden bir tanesi de enzim tabanlı DNA sitozin metilasyonunun varlığına ya da yokluğuna dayanan bir yaklaşımdır. Bu yaklaşım kullanılarak biyolojik aktiviteleri ve terapötik potansiyeli olan Nigella sativa L. genotipleri için rastgele genlerde DNA sitozin metilasyonu araştırılmıştır. Bu çalışmada, beş farklı Nigella sativa L. türüne ait genotipler (Çameli, Eskişehir, Konya, Suriye, Şanlıurfa) arasındaki sitozin metilasyon farklılıklarını araştırmak için touch-down polimeraz zincir reaksiyonları metilasyon duyarlı-rastgele arttırılmış polimorfik DNA (TD-MS RAPD) tekniği kullanılmıştır. Bu genotipler fidelerinden izole edilen genomik DNA örnekleri touch-down polimeraz zincir reaksiyonlarından önce metilasyona duyarsız olan $M s p I$ restriksiyon enzimi ve metilasyona duyarlı HpaII restriksiyon enzimi ile muamele edilmiştir. Kullanılan 8 oligonükleotid primerinden bir primer (OPB-12), beş genotip arasında metilasyon polimorfizmleri ile sonuçlanmıştır. TD-MS-RAPD-PZR yöntemi basit ve temel cihazları gerektiren uygun maliyetli yöntemdir. Bu yöntem normal bir DNA termal döngü cihazı ve DNA jel elektroforez sistemi kullanılarak kolayca uygulanabilmektedir. Ancak bu yöntemle saptanan metilasyon polimorfizmlerinin düzeyi çörek otunda çok düşüktür. Beş farklı çörek otu genomu arasında düşük düzeyde polimorfizm olduğu sonucuna varılmış olup bu durum çörek otu genomunun 5'-CCGG-3' içeriklerinin düşük olmasından kaynaklandığı düşünülmektedir.

Anahtar Kelimeler: Çörek otu, Epigenetik, MspI-HpaII

\section{Determination of DNA Cytosine Methylation Polymorphism Using RAPD Markers in Some Nigella sativa L. Genotypes}

ABSTRACT: Epigenetics is defined as heritable changes in gene expression and function without DNA base changes. Methylation in DNA and chemical modification in histone proteins are the two most studied epigenetic mechanisms in plants. There exist low-throughput and high-throughput DNA methylation detection techniques in epigenetic research. One of the low-throughput techniques is an enzyme-based approach based on the presence or absence of DNA cytosine methylation. Using this approach, DNA cytosine methylation in random genes was investigated for Nigella sativa L. varieties with biological activities and therapeutic potential. This study, touch-down polymerase chain reactions methylation sensitiverandom amplified polymorphic DNA (TD-MS RAPD) technique was used to investigate cytosine methylation differences among genotypes of five different Nigella sativa L. species; Çameli, Eskişehir, Konya, Suriye and Şanlıurfa. Genomic DNA samples extracted from the seedlings of these genotypes were treated with $M s p I$, a relative methylation-insensitive restriction enzyme and HpaII, a methylation-sensitive restriction enzyme before touch-down polymerase chain reactions. Among 8 oligonucleotide primers used, one primer (OPB-12) resulted in methylation polymorphisms among the five genotypes. The TD-MS-RAPD-PCR method is a simple and cost-effective method that requires basic equipment. This method can be easily implemented using a normal DNA thermal cycler and DNA gel electrophoresis system. However, the level of methylation polymorphisms detected with this method is very low in black cumin. It was concluded that there is a low level of polymorphism among five different black cumin genomes, which is thought to be due to the low 5'-CCGG-3' contents of the black cumin genome.

Key words: Black cumin, Epigenetic, MspI-HpaII

\footnotetext{
${ }^{1}$ Emine UYGUR GÖÇER (물d ID: 0000-0002-6967-7357), Iğdır Üniversitesi, Ziraat Fakültesi, Tarla Bitkileri Bölümü, IĞDIR, Türkiye

*Sorumlu Yazar/Corresponding Author: Emine UYGUR GÖÇER, e-mail: emine.uygur@igdir.edu.tr

Makale 15-17 Kasım 2021 tarihlerinde Iğdır'da düzenlenen “Türkiye 7. Tohumculuk kongresi” sözlü olarak sunulmuştur.
} 


\section{GíRiș}

Ranunculaceae familyası yaklaşı 70 cins ve 3000 tür içeren büyük bir familyadır. Nigella sativa L. Düğün çiçeğigiller (Ranunculaceae) familyasından yaklaşık 20 türü kapsayan Batı Asya'dan Kuzey Hindistan'a kadar uzanan Akdeniz bölgesine özgü tek yıllık bir bitki cinsidir (Weiss, 2002). Çeşitli şifalı bitkiler arasında Nigella sativa, birçok araştırmanın geniş farmakolojik potansiyelini ortaya çıkarması nedeniyle zengin bir tarihsel ve dini geçmişe sahip bir mucize bitki olarak ortaya çıkmaktadır. Dünya da Nigella sativa tohumları ve yağları yüzyıllar boyunca çeşitli hastalıkların tedavisinde yaygın olarak kullanılmaktadır (Ahmad ve ark., 2013).

Nigella sativa biyolojik aktiviteleri ve terapötik potansiyeli için kapsamlı bir şekilde incelenmiş ve antihipertansif, antidiyabetik, antikanser, antimikrobiyal, mide koruyucu, karaciğer koruyucu, böbrek koruyucu ve antioksidan özelliğe sahip olduğu gösterilmiştir. Bunun yanında tohumları bronşit, astım, ishal, romatizma ve cilt rahatsızlıkları gibi çeşitli hastalıkların tedavisinde yaygın olarak kullanılmaktadır. Bu bitkinin terapötik özelliklerinin çoğu, uçucu yağın ana aktif kimyasal bileşeni olan timokinon (TQ) varlığından kaynaklanmaktadır. Çörek otu toksisitesi çok düşük olduğu için ekmek ve turşularda tatlandırıcı katkı maddesi gibi gıdalarda da kullanılmaktadır (Abel-Salam, 2012).

Gen anlatımı, sadece DNA'da bulunan baz dizileriyle değil aynı zamanda kromozomal yapıların da dahil olduğu DNA ile etkileşen protein, RNA ve diğer makro moleküllerle de kontrol edilir (Tchurikov, 2005). DNA dizi değişimi dışında ortaya çıkan etkiler epigenetik etki olarak bilinmektedir. Diğer bir ifadeyle epigenetik terimi, DNA dizi değişimi olmaksızın sadece mitotik değil mayotik kalıtımla da meydana gelen gen ekspresyonundaki değişiklikler olarak tanımlanmaktadır (Wu ve Morris, 2001). Epigenetik düzenlemeler arasında en iyi anlaşılmış olan mekanizma DNA molekülünde özel pozisyonlarda bulunan C (sitozin) metilasyonudur (Bestor, 2000; Bird, 2002).

Metilasyon, örneğin sitozin bazının beşinci atomundaki metilasyon, genellikle DNA'ya bağlanan proteinleri değiştirerek ve ökaryotlarda temel bir DNA paketleme birimi olan nükleozomu değiştirerek gen anlatımındaki değişikliklere sebep olur. Bitkilerde DNA dizisini değiştirmeden yeni koşullara evrimsel adaptasyona izin veren DNA metilasyonu, doku ve organ gelişimi sırasında gen anlatımının ayarlanmasını, biyotik ve abiyotik uyaranlara yanıt verilmesini içerir (Osabe ve ark., 2014; Karaca ve ark., 2016; Karaca ve İnce, 2018). Soğuk, kuraklık, tuz, metaller ve gelişimsel değişiklikler (fide, olgunlaşma, çiçeklenme, meyve verme) dahil olmak üzere çevresel streslere metilasyon tepkileri incelenmiştir. Birçok çalışma olgunlaşma, tuzluluk, kuraklık ve metal stresleri gibi streslere tepki olarak metilasyonda (hipermetilasyon) veya demetilasyonda (hipometilasyon) bir artışa neden olduğunu göstermiştir.. Ancak, organizmalar veya gelişim evreleri arasında hipometilasyon veya hipermetilasyon yaygın değildir (Karaca ve İnce, 2018). Epigenetik düzenlemeler yalnızca çevresel uyaranlara yanıt vermeyi içermez, aynı zamanda meyve olgunlaşması, tohum boyutu, çiçeklenme zamanı, bitki boyutu, heterosis, bitki boyu, cinsiyet belirleme ve patojen direnci gibi diğer tarımsal açıdan önemli özelliklerin ifadesini de içerir (Osabe ve ark., 2014; Tiwari ve ark., 2015).

Canlı organizmalarda farklı DNA metilasyon türleri vardır. Bitki genomunda metillenmiş sitozinler genellikle CG, CHH veya $\mathrm{CHG}$ [H; Adenin (A), Timin (T) veya Sitozin (C)] dizilerini içeren bölgelerde yer almaktadır (Cokus ve ark., 2008; Karaca ve ark., 2016). Genlerin DNA sitozin metilasyonunda ki veya demetilasyonunda ki değişiklikler genetik kontroller ile epigenetik düzenlemeler altında olabileceğini göstermektedir (Osabe ve ark., 2014; Wang ve ark., 2016). DNA dizileme yöntemleri genel olarak aşağıdakiler gibi üç kategoriye ayrılabilir (i) belirli nükleotid de baz çiftinde çözünürlük üreten gene veya lokusa özgü yöntem. (ii) sekanslama çalışmaları tarafından ekzon sekanslama veya genotiplemeyi içeren bölgesel veya orantılı yöntemler ve (iii) Tüm genom sekanslama 
yöntemleri (Karaca ve Ince, 2008). DNA düzeyinde metilasyonun saptanmasında yukarıda bahsedilen bu üç kategori kullanılabilir. Metilasyon çalışmalarında eski veya modifiye edilmiş yöntemler veya yeni metodlardan yararlanılabilir (Karaca ve Ince., 2008; Ince ve ark., 2010a; Ince ve Karaca., 2011a).

Eski veya modifiye yöntemlerin örnekleri arasında metilasyona duyarlı çoğaltılmış polimorfizm (MSAP), çoğaltılmış parça uzunluk polimorfizminin (AFLP) bir modifikasyonu, metilasyona duyarlı rastgele arttırılmış polimorfik DNA (MS-RAPD), rastgele amplifiye edilmiş polimorfik DNA'nın (RAPD) bir modifikasyonu yer alır. Metilasyona duyarlı tek zincirli konformasyon polimorfizmi (MS SSCP), metilasyon duyarlı basit dizi tekrarlar arası polimorfizm (MS-ISSR) ve diğerleri (Karaca ve ark., 2008; Tiwari ve ark., 2015; Wang ve ark., 2016). Rastgele arttırılmış polimorfik DNA (RAPD), önceden genom bilgisi gerektirmeden türler arasındaki DNA polimorfizmini incelemek için yaygın olarak kullanılan bir tekniktir (Welsh ve McClelland, 1990; Williams ve ark., 1990; Ince ve ark., 2015). RAPD tekniğinde genellikle çoğaltmada tüm organizmalar için aynı oligonükleotid primer seti kullanılabilmektedir ve bu oligonükleotid özgün bölgelere rastgele bağlanarak çoğaltma yapmaktadır (İnce ve ark., 2015). İki örnek arasında boyut farkı gösteren amplifiye ürünlere polimorfik RAPD markırları denir. RAPD PCR tekniğinde genel olarak bant adı verilen yoğun ve hafif amplifiye ürün olarak iki tip amplifiye ürün üretilir. Yeniden üretilebilen RAPD bantları genellikle yoğun olan ve iki primer ile üretilebilen bantlardır. Hafif bantlar ise tek primerle üretilen genellikle tekrarlanamayan amplifiye ürünlerdir. RAPD PCR markırları polimorfizmi saptamak için hızlı bir yöntem olduğuı için birçok genetik çalışmada kullanılmaktadır (Welsh ve McCelland, 1990; Ince ve ark., 2010b; Ince ve Karaca, 2011b; Tiwari ve ark., 2015).

Bu çalışmanın temel amacı, DNA polimorfizmlerinin tespiti için en eski ve en basit yöntemlerden biri olan touch down tabanlı metilasyona duyarlı rastgele amplifiye polimorfik DNA markır (TD-MSRAPD-PCR) yönteminin güvenilir bir şekilde kullanılıp kullanılamayacağını araştırmak ve epigenetik bir mekanizma olan DNA sitozin metilsyonunu çörek otu bitkisinde uygulamaktır.

\section{MATERYAL VE METOT}

Çalışmada 5 çörek otu genotipi kullanılmış olup bunlardan dördü Türkiye'nin farklı bölgelerinden (Çameli, Eskişehir, Konya, Şanlıurfa) toplanmış olup bir tanesi Suriye'den getirilmiştir.

\section{DNA İzolasyonu}

Genomik DNA izolsyonu her bir genotipten 3'er tohum çimlendirerek elde edilen 7. gün fidelerini ait yaprak dokusu sıvı nitrojen kullanarak Aydın ve ark. (2018)'a ait, DNA izolasyon protokolü modifiye edilerek gerçekleştirilmiştir. İzole edilen genomik DNA örnekleri, spektrofotometrik analiz ve agaroz jel elektroforezi kullanılarak kantitatif ve kalitatif analizleri gerçekleştirilmiştir.

\section{Restriksiyon Enzim Kesimi İşlemi}

Restriksiyon enzim kesimi reaksiyonları $0.2 \mathrm{ml}$ 'lik ince duvarlı mikrotüplerde gerçekleştirilmiştir. $20 \mu \mathrm{L}$ reaksiyon karışımı 1000 ng genomik DNA, 10 ünite $\underline{M s p I}$ veya HpaII restriksiyon enzimleri ve 2 $\mu \mathrm{L}$ 10x DNA kesme tamponu (Tango buffer, Thermo Scientific) kapsamaktadır ve bu karışım $37^{\circ} \mathrm{C}$ 'de 16 saat inkübe edilmiştir (Karaca ve ark., 2005). İnkübasyonun sonunda her numuneye $150 \mu \mathrm{L}$ su ilave edilmiş ve TD-MS-RAPD-PCR deneylerinden önce iyice karıştırılmıştır.

\section{Touch-down Polimeraz Zincir Reaksiyonu (TD-PCR)}

DNA amplikasyonları, SimpliAmp 9700 termal döngüleyici PZR cihazında (Applied Biosystems by Thermo Fisher Scientific) gerçekleştirilmiştir. Reaksiyonlar, kalıp DNA, primerler, 10x reaksiyon tamponu, $\mathrm{MgCl}_{2}$, dört farklı dNTP ve Taq DNA polimerazı içeren $25 \mu \mathrm{L}$ 'lik bir reaksiyon karışımında Çizelge 1'de gösterildiği gibi gerçekleştirilmiştir. RAPD PCR reaksiyonlarının özgüllüğünü artırmak 
için ise Çizelge 2'de gösterildiği gibi bir touch-down PZR kullanılarak hedefler çoğaltılmıştır. MspI ve HpaII (Çizelge. 3) ile kesilmiş çörek otu numuneleri, toplam 8 oligonükleotid primeri kullanılarak çoğaltılmıştır (Çizelge 4).

Çizelge 1. TD-MS-RAPD için PZR reaksiyon karışımı

\begin{tabular}{|c|c|c|c|c|}
\hline \multicolumn{2}{|c|}{ Kullanılan Kimyasallar } & Stok & Miktar & Final \\
\hline \multicolumn{2}{|l|}{ Genomik DNA } & & $8.5 \mu 1$ & $100-120 \mathrm{ng}$ \\
\hline \multicolumn{2}{|l|}{ Steril- $\mathrm{H}_{2} \mathrm{O}$} & & $3.5 \mu 1$ & \\
\hline \multicolumn{2}{|c|}{ İleri Primer ("Forward") } & $20 \mu \mathrm{M}$ & $3.0 \mu 1$ & $2.4 \mu \mathrm{M}$ \\
\hline \multicolumn{2}{|l|}{ Steril- $\mathrm{H}_{2} \mathrm{O}$} & & $4.6 \mu 1$ & \\
\hline 10X Reaksiyon & TRIS-HCI (pH 9.1) & $100 \mathrm{mM}$ & $3 \mu 1$ & $12 \mathrm{mM}$ \\
\hline \multirow[t]{2}{*}{ Çözeltisi } & $\mathrm{KCI}$ & $100 \mathrm{mM}$ & & $60 \mathrm{mM}$ \\
\hline & Triton $X-100$ & $\% 0.1$ & & $\% 0.012$ \\
\hline \multicolumn{2}{|l|}{$\mathrm{MgCI}_{2}$} & $50 \mathrm{mM}$ & $1.5 \mu 1$ & $3 \mathrm{mM}$ \\
\hline \multicolumn{2}{|l|}{ dNTP } & $10 \mathrm{mM}$ & $0.7 \mu 1$ & $0.28 \mathrm{mM}$ \\
\hline \multicolumn{2}{|l|}{ Taq DNA Polimeraz } & 5 ünite/ $\mu 1$ & $0.2 \mu 1$ & 1 ünite \\
\hline \multicolumn{2}{|l|}{ Toplam Hacim } & \multicolumn{2}{|c|}{$25 \mu 1$} & \\
\hline
\end{tabular}

Çizelge 2. TD-MS-RAPD-PCR profili

\begin{tabular}{llccc}
\hline PZR Profili & & Zaman & Döngü Sayıs & Aşama \\
\hline Hot Start & $94^{\circ} \mathrm{C}$ & 5 dakika & 1 döngü & Ön-denatürasyon \\
Ön PZR & $94^{\circ} \mathrm{C}$ & 1 dakika & 10 döngü & Denatürasyon \\
& $42^{\circ} \mathrm{C} \rightarrow 37^{\circ} \mathrm{C}$ & $1 \mathrm{dk} 20 \mathrm{sn}$ & & Renatürasyon \\
& $72^{\circ} \mathrm{C}$ & 2 dakika & & Sentez \\
PZR & $94^{\circ} \mathrm{C}$ & 2 dakika & 30 döngü & Denatürasyon \\
& $37^{\circ} \mathrm{C}$ & 1 dk $20 \mathrm{sn}$ & & Renatürasyon \\
& $72^{\circ} \mathrm{C}$ & 2 dakika & & Sentez \\
Final & $72^{\circ} \mathrm{C}$ & 10 dakika & 1 döngü & Final Sentez \\
& $4^{\circ} \mathrm{C}$ & 1 saat & & \\
\hline
\end{tabular}

Çizelge 3. CCGG metilasyon durumuna MspI ve HpaII restriksiyon enzimlerinin duyarlılıkları

\begin{tabular}{|c|c|c|c|}
\hline Hedef Bölge & Msp I & Hра II & Metilasyon Durumu \\
\hline CCGG/GGCC & Keser & Keser & Her iki DNA sarmalıda metlsizidr. \\
\hline C'CGG/ & Keser & Kesmez & İçteki Sitozin bazları tamamen metillidir \\
\hline $\begin{array}{l}\mathbf{G G}^{\mathrm{m}} \mathbf{C C} \\
{ }^{\mathrm{m}} \mathbf{C}^{\mathrm{m}} \mathbf{C G G} / \\
\text { GGCC }\end{array}$ & Kesmez & Keser & Bir DNA sarmalı tamamen metillidir. \\
\hline${ }^{\mathrm{m}}$ CCGG/GGCC & Kesmez & Keser & Bir DNA sarmalı yarı metillidir \\
\hline $\begin{array}{l}{ }^{\mathrm{m}} \mathbf{C}^{\mathrm{m}} \mathbf{C G G} / \\
\mathbf{G G}^{\mathbf{m}} \mathbf{C}^{\mathrm{m}} \mathbf{C}\end{array}$ & Kesmez & Kesmez & Her iki DNA sarmalıda tam metillidir \\
\hline
\end{tabular}

Çizelge 4. Çalışmada kullanılan oligonükleotid primer dizileri

\begin{tabular}{llllllcc}
\hline NO & Primer ID & Primer sequence 5' $\rightarrow \mathbf{3}^{\prime}$ & Çameli & Eskişehir & Konya & Şanlıurfa & Suriye \\
\hline $\mathbf{1}$ & OPA-06 & GGTCCCTGAC & 2 & 2 & 2 & 2 & 2 \\
$\mathbf{2}$ & OPB-12 & CCTTGACGCA & $8(+1)$ & $6(+1)$ & $6(+1)$ & $6(+1)$ & $6(+1)$ \\
$\mathbf{3}$ & OPC-08 & TGGACCGGTG & 5 & 6 & 6 & 6 & 6 \\
$\mathbf{4}$ & OPD-02 & GGACCCAACC & 4 & 3 & 4 & 3 & 3 \\
$\mathbf{5}$ & OPG-03 & GAGCCCTCCA & 4 & 4 & 4 & 3 & 4 \\
$\mathbf{6}$ & OPH-10 & CCTACGTCAG & 3 & 4 & 4 & 4 & 4 \\
$\mathbf{7}$ & OPK-15 & CTCCTGCCAA & 1 & 1 & 1 & 1 & 1 \\
$\mathbf{8}$ & OPK-18 & CCTAGTCGAG & 2 & 2 & 2 & 2 & 2 \\
\hline
\end{tabular}




\section{Agaroz Jel Elektroforezi}

TD-MS-RAPD-PCR deneyleri yapıldıktan sonra, her $25 \mu \mathrm{L}$ PZR ürününe $5 \mu \mathrm{L}$ 6x DNA yükleme tampon çözeltileri eklenmiş ve iyice karıştırılmıştır. Bu karışımlar, $0.05 \mu \mathrm{g} / \mathrm{mL}$ etidyum bromür içeren \%1.5-3 yüksek çözünürlüklü agaroz jellere yüklendikten sonra 1x Tris Borate-EDTA tamponu varlığında 3 ila 6 saat sabit voltajda 5 V/cm'de elektroforez yapılmış ve analiz için bir ultraviyole (UV) transillüminatör üzerinde fotoğraflanmıştır (Karaca ve ark., 2013).

\section{Sitozin Metilasyon Skorlaması}

TD-MS-RAPD-PCR markırları Msp I ve Hpa II enzimi ile kesilen 5 farklı çörek otu genomik DNA'ları arasında var (1) ve yok (0) olarak skorlama yapılmıştr. Bir TD-MS-RAPD-PCR markırının yokluğu, her iki hedef dizisinin de metillenmemiş tetra-nükleotitler içerdiği kabul edilir (5'-CCGG-3'/3'GGCC-5') iken, bir TD-MS RAPD-PCR markırının varlığı, her iki hedef dizisinin de tamamen metillenmiş tetra-nükleotitler (5'-mCmCGG3/3'-GGmCmC-5') içerdiğgi kabul edilmiştir. TD-MSRAPD-PCR markırının MspI' da var HpaII' de yok olması DNA zincirinin tamamen metillenmiş (5'mCmCGG-3'/3'-GGCC-5') olduğu ya da yarı metillenmiş (5'-mCCGG-3'/3'-GGCC-5') olduğu düşünülmüştür. Öte yandan, MspI'da bir TD-MS-RAPD-PCR markırı bulunmadığında ancak aynı markır Hpa II özetinde mevcut olduğunda, bu durumda da içteki sitozin bazlarının tamamen metillenmiş olduğu düşünülmüştür (5'-CmCGG-3' /3'-GGmCC-5'). Bu çalışmada 1 ve 0 puanlaması kullanılmıştır. Var (1) olarak puanlanması hedefin enzim tarafından kesilmediği, yok olarak (0) puanlanması ise hedefin enzim tarafından kesildiği kabul edilmiştir.

\section{BULGULAR VE TARTIŞMA}

$\mathrm{Bu}$ çalışmada, olgun çörek otu fidelerinde DNA sitozin metilasyonunun tespiti için TD-MSRAPD-PCR tekniğini kullanılmıştır. TD-MS-RAPD-PCR tekniğinin kullanımı, aynı tanıma bölgelerine sahip olan ancak DNA metilasyonuna karşı farklı hassasiyet gösteren birbirlerinin izoşizomerleri olan MspI ve HpaII enzimlerinin uygulanmasına dayanmaktadır. Bu enzimler 5'-CCGG-3' dizilerini tanır ve HpaII enzimi sadece tek bir DNA zinciri metillendiğinde (hemimetillendiğinde) diştaki sitozinler, $M s p I$ ise her iki DNA zinciri de tamamen metillendiğinde içteki sitozinleri keser. Ancak her iki DNA zinciri de metillenmediğinde her iki enzim de hedefleri keser. Çizelge 3 MspI ve HpaII'nin kesme davranışlarını özetlemektedir (Salmon ve ark., 2008). İki farklı hat veya çeşidi temsil eden iki farklı genomik DNA örnekleri MspI ve Hpa II ile kesildiğinde 5'-CCGG-3' hedef bölgelerinde farklı metilasyon paternleri varsa, ayırt edilebilirler. Öte yandan, hedef diziler metillenmemiş ve tamamen metillenmiş olduğunda iki çeşit veya hat ayırt edilemez (Tiwari ve ark., 2015).

$\mathrm{Bu}$ çalışmada, MS-RAPD-PCR markırlarının amplifikasyonu, artefakt adı verilen spesifik olmayan markırların amplifikasyonunu en aza indirmek için bir touch-down PZR profili (TD-MSRAPD-PCR olarak adlandırılır) kullanılarak gerçekleştirilmiştir. RAPD tekniğinde artifak amplikonların üretilmesi, markırların tekrarlanabilirliğini azalttığı için RAPD yönteminin ana dezavantajlarından biridir (Karaca ve Ince, 2008).

Güvenilir bir şekilde puanlanabilen çoğaltılmış ürünlerin sayısı 8 primer arasında değişiklik göstermiştir (Çizelge 4). Örneğin OPK-15 oliganükleotid primeri 1 TD-MS RAPD-PCR markırı üretirken OPB 12 markırı en yüksek değeri sekiz (8) üretmiştir. Bu çalışmada Çameli, Eskişehir, Konya, Şanlıurfa ve Suriye genotipleri ile temsil edilen beş çörek otu türü arasında TD-MS-RAPD-PCR markırlarının sayısıda değişiklik göstermiş olup toplam Çameli genotipinde 29, Eskişehir genotipnde 28, Konya genotipinde 29, Şanlıurfa genotipinde 27 ve Suriye genotipinde 28 TD-MS-RAPD-PCR markırı bulunmaktadır. 
Kullanılan 8 primerden sadece biri (OPB 12) Şekil 1'de gösterildiği gibi çalışılan çörek otu genotipleri arasında metilasyona duyarlı polimorfizmler saptandı. Primer OPB12 ile amplifiye edilen lokus, tamamen metillenmiş iç sitozin bazları (5'-CCGG-3'/3'-GGCC-5') içermektedir. Bununla birlikte, bu metilasyonlar, çörek otu genotipleri arasında polimorfik olmadığı tespit edilmiştir.. Öte yandan Çameli genotipinde bir TD-MS-RAPD-PCR markırı (OPC 08) çalışmada ki diğer çörek otu genotiplerinde bulunmadığı için genotipler arasında metilasyon polimorfizmi ortaya çıkmıştır. (Şekil 2 'de panelin ortasındaki bir okla gösterildiği gibi).

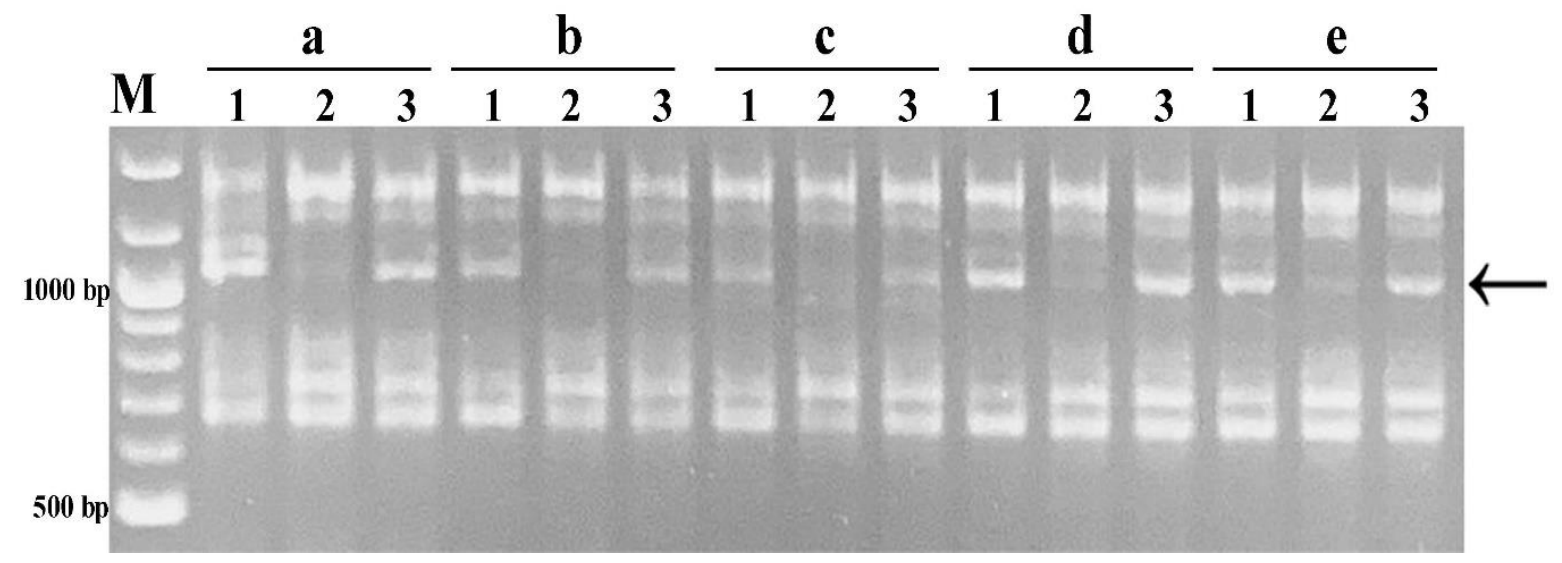

Şekil 1. a) Çameli, b) Eskişehir, c) Konya, d) Şanlıurfa, e) Suriye Genomik DNA'larının MspI ve HpaII enzimleri ile kesim sonras1 OBP 12 primeri ile TD-MS-RAPD-PCR sonucu 1) Kontrol, 2) MspI enzimi metilasyon paternleri, 3) HpaII enzimi metilasyon paternleri

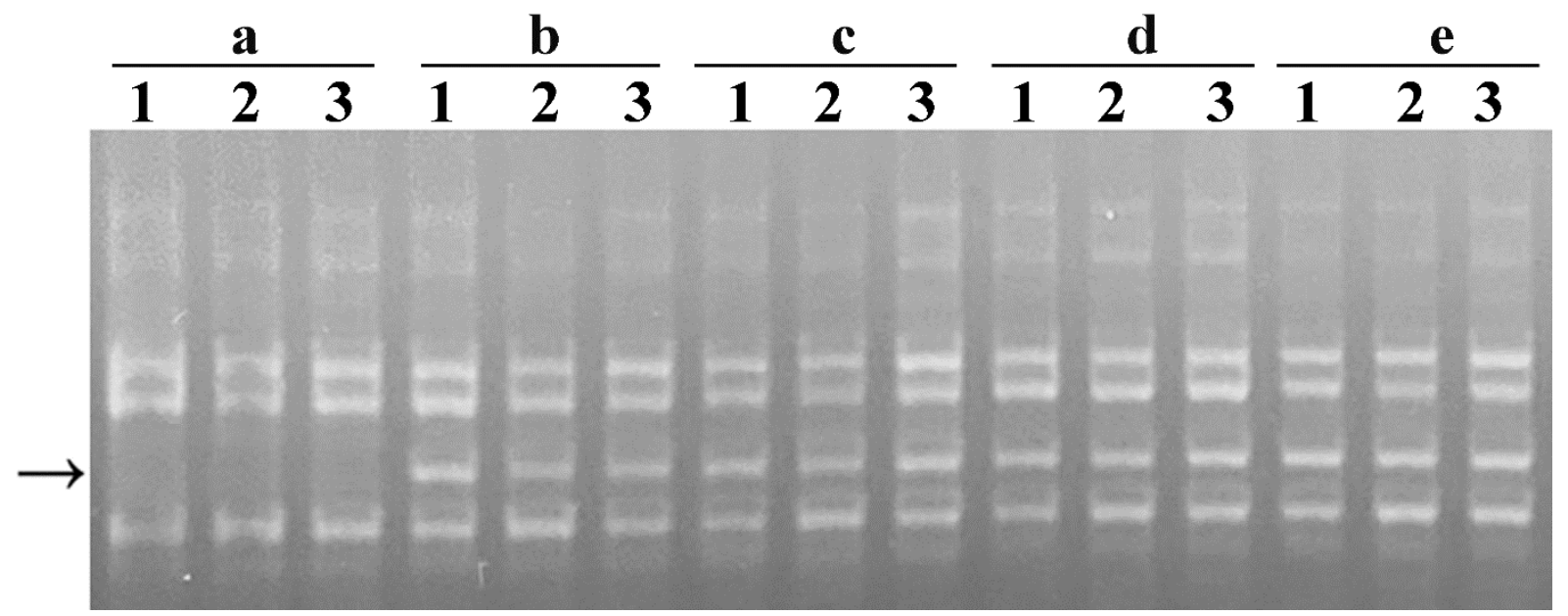

Şekil 2. a) Çameli, b) Eskişehir, c) Konya, d) Şanlıurfa, e) Suriye Genomik DNA'larının MspI ve HpaII enzimleri ile kesim sonrasi OPC 08 primeri ile TD-MS-RAPD-PCR sonucu 1) Kontrol, 2) MspI enzimi metilasyon paternleri, 3) HpaII enzimi metilasyon paternleri

Bu çalışmada, TD-MS-RAPD-PCR sonuçlarına dayanarak, çörek otu fidelerinin genomik DNA örneklerinin 5'-CCGG-3' bölgelerinde düşük düzeyde DNA metilasyon farklılıklarına sahip olduğu belirlenmiştir. Örneğin, Osabe ve ark. (2014), DNA metilasyonu çeşitliliği, seçilen bitki genotiplerinde genetik çeşitlilikten daha büyük olduğu ve dokular arasında önemli ölçüde farklı DNA metilasyonu seviyeleri olduğunu tanımlamışlardır. Bu çalışmada CG bölgesindeki metilasyon incelenmiştir. Ancak çörek otundaki genetik ve epigenetik değişikliklerden en çok etkilenen genomik bölgeleri incelemek için CHG ve CHH bölgelerine de özgü enzimle metilasyon farklılıklarını tespit etmek için kullanılabilir.

Beş farklı çörek otuna ait genomdan elde edilen TD-MS-RAPD-PCR markırlarına dayalı olarak elde ettiğimiz sonuçlar, çörek otu fidelerinin DNA metilasyon polimorfizmlerinin çörek otundaki 
genomik metilasyon polimorfizminden daha az olduğunu göstermiştir. Bununla birlikte, TD-MSRAPD-PCR'nin sadece 5'-CCGG-3' dizisinde bulunan sitozin bazlarının metilasyonunu ayırt edebildiğini de söyleyebiliriz. Ayrıca, literatürde bildirildiği gibi (Wang ve ark. 2016) çörek otu genomunda 5'-CCGG-3' bölgelerinin oluşumunun düşük olduğunu, dolayısıyla diğer bazı kısıtlamaların olduğunu doğruladığımızı da belirtmeliyiz. TD MS-RAPD-PCR yönteminde çörek otundaki metilasyon farklılıklarını arttırmak için CG, CHG ve CHH bölgelerine özgü enzimler kullanılabilir olduğu sonucuna varılmıştır.

\section{SONUÇ}

Bu çalışmada, 5 çörek otu genotipi arasında 5'-CCGG-3' sekans bölgesinde DNA sitozin metilasyon farklılıklarını araştırmak için touch-down (TD) tabanlı metilasyona duyarlı (MS) rastgele amplifiye polimorfik DNA (RAPD) polimeraz zincir reaksiyonu (PZR) yöntemi (TD-MS-RAPD-PCR) kullanılmıştır. Hedef genomik DNA örnekleri, her bir genotip için çimlendirilen fidelerden ekstrakte edilmiştir. Kullanılan 8 oligonükleotid primerinden sadece bir primer (OPB 12) epigenetik polimorfizmlerle sonuçlanmıştır. Böylece çörek otu genomlarının yüksek oranda 5'-CCGG-3' bölgeleri içermediği de doğrulanmış olmuştur. İncelenen 5'-CCGG-3' bölgelerinin çoğu, yüksek düzeyde DNA sitozin metilasyonları göstermediği çörek otu fidelerinden ekstrakte edilen genomik DNA örneklerinin farklı şekilde metillenmediği ortaya konulmuştur.

Sonuçlarımız, çörek otu örnekleri arasındaki genetik polimorfizmin DNA sitozin metilasyonundan (epigenetik) çok daha büyük olduğunu ortaya koymuştur. TD-MS-RAPD-PCR yöntemi uygun maliyetli olmasına, basit ve temel enstrümantasyon gerektirmesine ve normal bir DNA termal döngüleyici ve DNA jel elektroforez sistemi kullanılarak temel kuruluma sahip herhangi bir laboratuvarda kolaylıkla uygulanabilmesine rağmen çörek otu fideleri genomik DNA'sında tespit edilen polimorfizm seviyesi çok düşük olarak belirlenmiştir.

\section{Çıkar Çatışması}

Makalenin planlanması ve yazılması sırasında herhangi bir çıkar çatışması olmadığını beyan ederim.

\section{Yazar Katkısı}

Makalenin planlanması, yürütülmesi ve yazılmasının tarafımdan yapıldığını beyan ederim.

\section{KAYNAKLAR}

Abel-Salam BK, 2012. Immunomodulatory Effects of Black Seeds and Garlic on Alloxan-İnduced Diabetes in Albino Rat. Allergol Immunopathol (Madr), 40 (6): 336-340.

Ahmad A, Husain A, Mujeeb M, Khan SA, Najmi A, Siddique NA, Damanhouri ZA, Anwar F, 2013. A Review on Therapeutic Potential of Nigella Sativa: A Miracle Herb. Asian Pacific Journal of Tropical Biomedicine, 5 (3): 337-352.

Aydin A, Ince AG, Uygur Gocer E, Karaca M, 2018. Single Cotton Seed DNA Extraction without the Use of Enzymes and Liquid Nitrogen. Fresenius Environmental Bulletin and Advances in Food Sciences, 27: 6722-6726.

Bestor TH, 2000. Chromatin Challenges During DNA Replication and Repair. Human Molecular. Genetics, 9: 2395-2402.

Bird A, 2002. DNA Methylation Patterns and Epigenetic Memory. Genes and Development, 16: 6-21.

Cokus SJ, Feng S, Zhang X, Chen,Z, Merriman B, Haudenschild CD, Pradhan S, Nelson SF, Pellegrini M, Jakopsen SE, 2008. Shotgun Bisulphite Sequencing of the Arabidopsis Genome Reveals DNA Methylation Patterning. Nature, 452, 215-219. 
Ince AG, Karaca M, 2011a. Early Determination of Sex in Jojoba Plant by CAPS Assay. Journal of Agricultural Science and Technology, 149: 327-336.

Ince AG, Karaca M, 2011b. Genetic Variation in Common Bean Landraces Efficiently Revealed By Td-DAMDPCR Markers. Plant Omics, 4: 220-227.

Ince AG, Karaca M, Aydin A, Elmasulu SY, Turgut K, 2015.Microsatellites for Genetic and Taxonomic Research on Thyme (Thymus L.). Turkish Journal of Biology, 39: 147-159.

Ince AG, Karaca M, Onus AN, 2010a. Genetic Relationships within and Between Capsicum Species. Biochemical Genetics, 48: 83-95.

Ince AG, Karaca M, Onus AN, 2010b. Differential Expression Patterns of Genes Containing Microsatellites in Capsicum Annuum L. Molecular Breeding, 25: 645-658.

Karaca M, Ince AG, 2008. Minisatellites as DNA markers to classify bermudagrasses (Cynodon spp.): Confirmation of minisatellite in amplified products. Journal of Genetics 87: 84-86.

Karaca M, Ince AG, 2018. Primer Pairs for Rice (Oryza Sativa L.) Bisulfite Sequencing Studies. Journal Plant Science Phytopathol, 2: 091-098.

Karaca M, Ince AG, Aydin A, Ay ST, 2013. Cross-Genera Transferable E-Microsatellite Markers For 12 Genera of the Lamiaceae Family. Journal of the Science of Food and Agriculture, 93: 1869-1879.

Karaca M, Ince AG, Elmasulu SY, Onus AN, Turgut K, 2005. Coisolation of Genomic and Organelle DNAs from 15 Genera and 31 Species of Plants. Analytical Biochemistry, 34: 353-355.

Karaca M, Ince AG, Gocer EU, Aydin A, 2016. Exonic and İntronic DNA Methylation Differences in A Fiber Specific Gene of Pima Cotton (Gossypium Barbadense L.). Journal Science Engineering Research, 3: 478486.

Osabe K, Clement JD, Bedon F, Pettolino FA, Ziolkowski L, Llewellyn D, Jean Finnegan EJ, Wilson LW, 2014. Genetic and DNA Methylation Changes in Cotton (Gossypium) Genotypes And Tissues. PLoS ONE 9: e86049.

Salmon A, Clotault J, Jenczewski E, Chable V, Manzanares-Dauleux, MJ, 2008.Brassica oleracea Displays a High Level of DNA Methylation Polymorphism. Plant Science, 174, 61-70.

Tchurikov NA, 2005. Molecular Mechanisms of Epigenetics. Biochemistry, 70: 406-423.

Tiwari JK, Saurabh S, Chandel P, Singh BP, Bhardwaj V, 2015.Assessment of Genetic And Epigenetic Variations in Potato Somatic Hybrids By Methylation-Sensitive ISSR and RAPD Markers. Bangladesh Journa Botany, 44: 45-50.

Wang B, Zhang M, Fu R, Qian X, Rong P, Zhang Y, Jiang P, Wang J, Lu X, Wang D, Ye W, Zhu X, 2016. Epigenetic Mechanisms of Salt Tolerance and Heterosis in Upland Cotton (Gossypium Hirsutuml.) Revealed by Methylation-Sensitive Amplified Polymorphism Analysis. Euphytica, 208: 477-491.

Welsh J, McCelland M, 1990. Fingerprinting Genomes Using PCR with Arbitrary Primers. Nucleic Acids Research, 18: 7213-7218.

Williams JGK, Kubelik ARK, Livak J, Rafalski JA, Tingey SV, 1990. DNA Polymorphism Amplified by Arbitrary Primers is Useful as Genetic Markers, Nucleic Acid Res.earch, 18: 6531-6535.

Wu CT, Morris JR, 2001. Genes, Genetics and Epigenetics: A Correspondence. Science, 293: 1103-1105. 